\title{
Effects of Planting Dates and Varieties on Growth and Yield of Broccoli During Rainy Season
}

\author{
Karistsapol Nooprom and Quanchit Santipracha \\ Department of Plant Science, Faculty of Natural Resources, \\ Prince of Songkla University, Hat Yai, Songkhla, 90112, Thailand
}

Received 2013-10-19, Revised 2013-11-05; Accepted 2013-11-19

\begin{abstract}
Broccoli (Brassica oleracea var. italica) is one of the most popular vegetable crops in many countries of the world as its nutritional importance. It has the most exacting climatic and cultural requirements, which limit its commercial production to a few favored locations. In Thailand, broccoli has been expending in recent years and amount of increasing production. It is best planted in the North where the weather is cool or in the Northeast during winter season. The South has tropical climates and raining all year round, but farmers can produce broccoli during early summer by using the heat-tolerant varieties. Although the broccoli is highly priced and still wanted by consumers in the rainy season, the farmers might not choose to grow as the problems with low productivity. Thus, the selection of suitable planting dates and varieties is crucial for successful cultivation during rainy season in the South. The experiment was performed to evaluate the effects of planting dates and broccoli varieties on their growth and yield responses during rainy season. Four broccoli varieties: 'Top Green', 'Green Queen', 'Yok Kheo' and 'Special' were plated for six planting dates: July, August, September, October, November and December at Prince of Songkla University, Thailand, between July, 2011 and January, 2012. Split-plot in a randomized complete block design was used in this experiment with four replications. This study showed that four broccoli varieties had highly seedling survival rates of 70.31-99.22\% when planting in July-December except 'Special' of 54.68\% when planting in August. 'Yok Kheo' had plant diameter of 67.54-75.24 cm when planting in July and December, not significantly different from 'Top Green' planting in July, August and November of $69.15-71.24 \mathrm{~cm}$ and 'Green Queen' in July and September of 68.69-68.88 cm. The highest total yield was obtained by 'Yok Kheo' when planting in July and December of 7.73-7.87 tha $\mathrm{th}^{-1}$. It is anew interesting hybrid variety producing higher yields than 'Top Green' which is popular variety planted in southern Thailand. Therefore, 'Yok Kheo' is the suitable variety for production during rainy season in southern Thailand because it provides high growths and yields, especially in July and December.
\end{abstract}

Keywords: Broccoli, Humid Tropical Regions, Thailand

\section{INTRODUCTION}

Broccoli is a member of the Brassicaceae family as a wild form of this family. It is considered as a cool season crop. Its optimum temperature requirement is in the range of $16-20^{\circ} \mathrm{C}$ (Decoteau, 2000). Broccoli is an Italian vegetable natively in the Mediterranean region, cultivated in Italy' sancient Roman period and England in 1720 . On the other hand, in 1806, its first appeared in the United States of America, but the commercial cultivation was started around 1923 (Ouda and Mahadeen, 2008). It is one of the most important and popular vegetable crops in many countries of the world because of its good organoleptic properties and high nutritive value (Dhillon et al., 2005). In Thailand, broccoli is cultivated on the limited areas where the

Corresponding Author: Karistsapol Nooprom, Department of Plant Science, Faculty of Natural Resources, Prince of Songkla University, Hat Yai, Songkhla, 90112, Thailand 
weather is cool or during winter season (Nooprom et al., 2013b; Pornsuriya et al., 1997). There is an increasing trend of cultivation by farmers as well as consumers' consumption. The weather of southern Thailand is quite humid tropics which is unsuitable for the growth of general broccoli varieties, but suitable for the heattolerant hybrid broccoli varieties. They are better adapted to the high temperature of humid tropical regions allowing growth and giving high yields during dry season (Nooprom et al., 2013a). In rainy season, there is continuously heavy raining between September and December resulted in broccoli's low growths and yields (Santipracha, 2007). In this period of time, the broccoli has very low productivity and is highly wanted with pricey by the market as many areas of Thailand faced the same rainy problem.

The present study was conducted to evaluate the growths and yields of broccoli affected by different planting dates and varieties during rainy season in southern Thailand.

\section{MATERIALS AND METHODS}

This study was conducted at Prince of Songkla University, Hat Yai, Songkhla province, Thailand from July, 2011 to January, 2012. The design was a split-plot in a randomized complete block design with four replications. The main plots were planting dates: January, February, March, April, May and June with sub-plots being early varieties of broccoli: 'Top Green', 'Green Queen', 'Yok Kheo' and 'Special'. These varieties showed good performance such as early growth and yield when planting in Songkhla province of southern Thailand (Nooprom and Santipracha, 2011). Broccoli seed was sown in plastic baskets $(13 \times 16 \times 4$ inches). When the first true leaf had emerged, the seedlings were transplanted into 2 inch pots. At the fourth leaf stage, the seedlings were transplanted into the field. The plot size was $1 \times 5 \mathrm{~m}$. The plant and row spacing were $0.30 \times 0.60 \mathrm{~m}$ and the edge spacing was 0.2 $\mathrm{m}$. Each plot had two rows of 32 plants. Broccoli was regularly watered with a sprinkler early in the morning and early in the afternoon except rainy days. Fertilizer $21 \mathrm{~N}-0 \mathrm{P}-0 \mathrm{~K}$ was applied three times at 2, 3 and 4 weeks after transplanting. Moreover, fertilizer $15 \mathrm{~N}-6.5 \mathrm{P}-12.5 \mathrm{~K}$ was applied twice at 5 and 6 weeks after transplanting. All plots were weeded with a hand hoe, twice at 2 and 4 weeks after transplanting.

The measured data, seedling survival rate at 30 Days After Transplanting (DAT) was determined. The number of days from transplanting to the beginning of time to $50 \%$ flowering and harvest was observed in the plot. Other data were recorded such as, plant diameter, harvested plant, head diameter, head weight and total yield. Average of daily rainfall, minimum and maximum temperatures from July, 2011 to January, 2012 was received from the Kho Hong Agrometeorological Station, Hat Yai, Songkhla province, Thailand. The data were analyzed using the analysis of variance and means separated by Duncan's Multiple Range Test (DMRT) at the $5 \%$ level of significance.

\section{RESULTS}

\subsection{Growth Responses}

The interaction effected between planting dates and varieties on growth responses for seedling survival rate is differed from each variety over the range of planting dates. Four broccoli varieties had highly seedling survival rates of 70.31-99.22\% when planting between July and December (Fig. 1A) except 'Special', decreasing survival rate of seedling of $54.68 \%$ when planting in August. Plant diameters were significantly different from planting dates and varieties as well as a significant interaction effect. 'Yok Kheo' had the highest plant diameter of 67.54$75.24 \mathrm{~cm}$ (Fig. 1B) when planting between July and December. It was not significantly different from that of 'Top Green' when planting in July, August and November of 69.15-71.24 cm and 'Green Queen' when planting in July and September of 68.69-68.88 $\mathrm{cm}$. The interactions between planting dates and varieties were also significantly influenced on the time to $50 \%$ flowering and harvest. 'Green Queen' had the early time to $50 \%$ flowering of 30.00 DAT when planting in December (Fig. 1C). Its produced time to $50 \%$ flowering was late, of 32.75-43.00 DAT, when planting between July and November, but it produced much earlier flowering than 'Top Green', 'Yok Kheo' and 'Special' of 43.50-53.50 DAT given flowering in August and November, especially in August.These results were consistent with time to $50 \%$ harvest showing that 'Green Queen' had earlier time to $50 \%$ harvest than other varieties when planting in December of 40.50 DAT (Fig. 1D). While planting between July and November, it was late for time to $50 \%$ harvest of 41.25-53.25 DAT. The times to $50 \%$ harvest of 'Top Green', 'Yok Kheo' and 'Special' were later than of 'Green Queen' when planting in August and November of 53.50-64.00 DAT. 
K. Nooprom and Q. Santipracha / American Journal of Agricultural and Biological Sciences 8 (4): 357-361, 2013
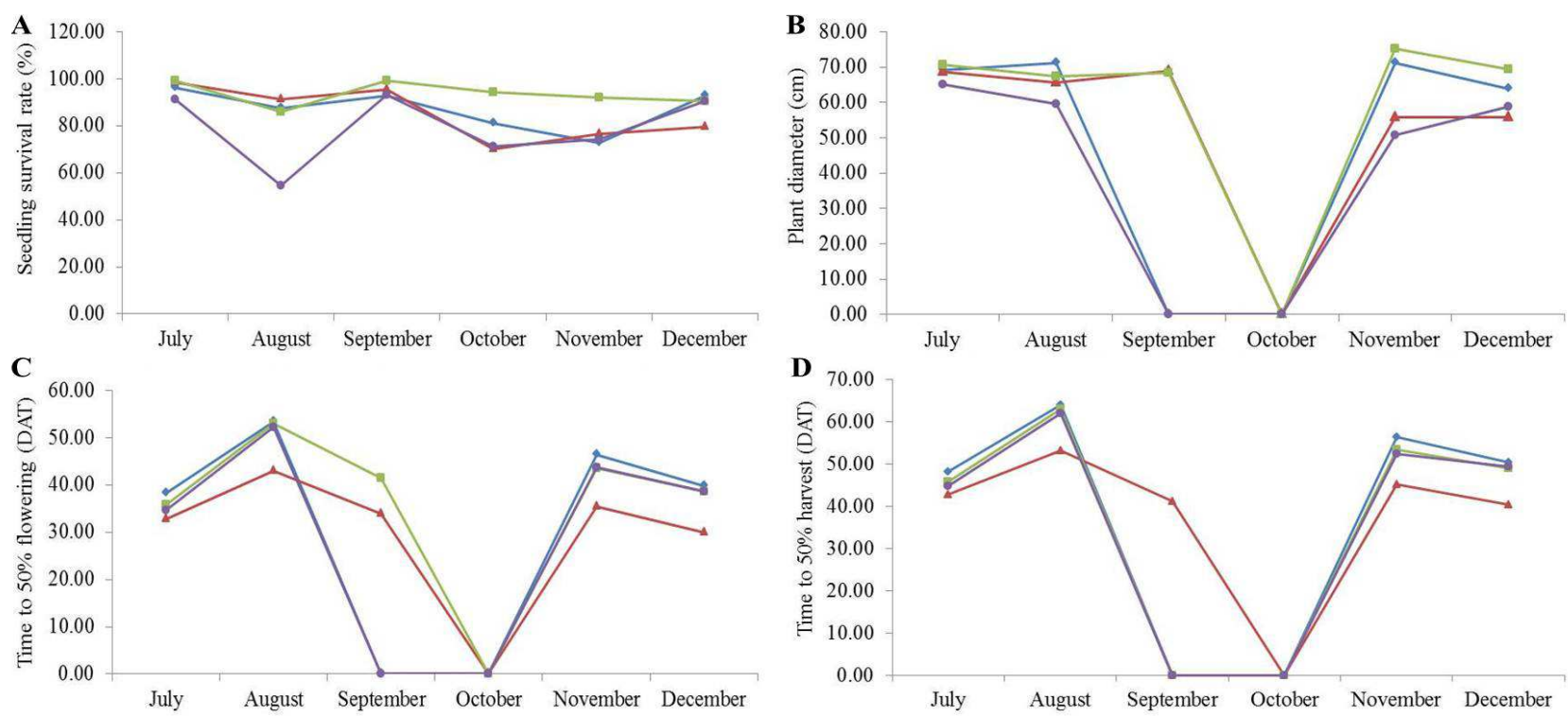

$\rightarrow$ Top Green $\rightarrow$ Green Queen $\quad \rightarrow$ Yok Kheo $\rightarrow$ Special

Fig. 1. Interactions between planting dates and varieties on seedling survival rate (A), plant diameter (B), time to 50\% flowering (C) and time to $50 \%$ harvest (D)

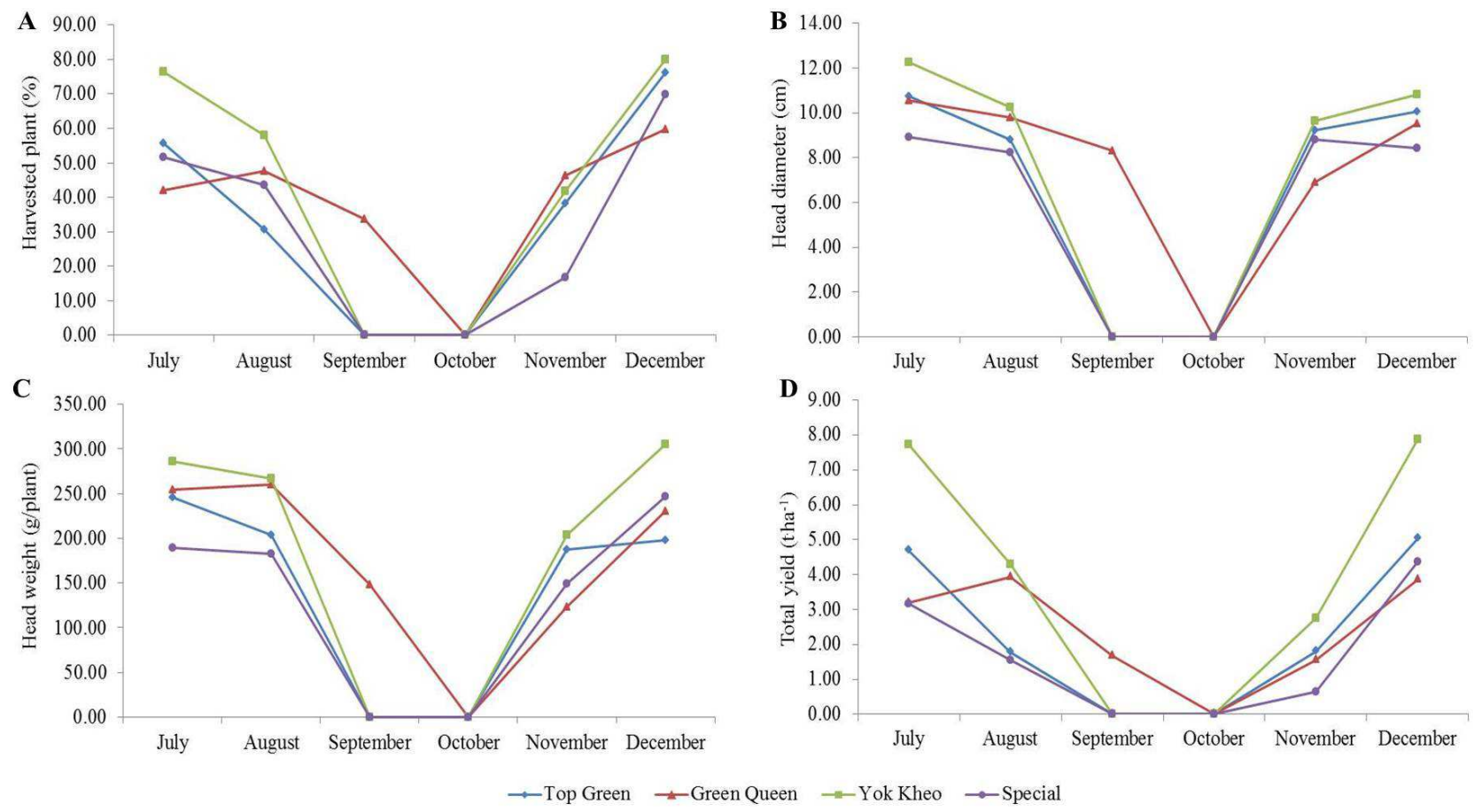

Fig. 2. Interactions between planting dates and varieties on harvested plant (A), head diameter (B), head weight (C) and total yield (D) 


\subsection{Yield Responses}

There were interaction effects of planting dates and varieties on yield responses. 'Yok Kheo' had the highest harvested plant of 76.34 to $80.04 \%$ (Fig. 2A) when planting in July and December. These results was not significantly different from 'Top Green' and 'Special' of 76.09 and $69.72 \%$, respectively when planting in December, followed by 'Green Queen' and 'Special' of $59.69-69.72 \%$ when planting in December. The interactions between planting dates and varieties were also significantly influenced on each particular head diameter and weight. The highest head diameter and weight of 'Yok Kheo' with July and December's planting were of $12.26 \mathrm{~cm}$ and $304.77 \mathrm{~g} /$ plant, respectively (Fig. 2B and C). The head diameter and weight were consistent with total yield of broccoli. 'Yok Kheo' had the highest total yield of 7.73-7.87 tha ${ }^{-1}$ when planting in July and December (Fig. 2D), followed by 'Top Green' when planting in July and December (4.70-5.04 $\left.\mathrm{tha}^{-1}\right)$, 'Special' in December (4.37 tha ${ }^{-1}$ ), 'Yok Kheo' in August (4.31 tha $\left.{ }^{-1}\right)$ and 'Green Queen' in August and December (3.87-3.94 tha $\left.{ }^{-1}\right)$. In September and
October, all broccoli total yields dropped to $0.00 \mathrm{tha}^{-1}$. After October, they had increasing total yields.

\section{DISCUSSION}

Growth and yield responses of broccoli revealed that 'Special' had the lowest seedling survival rate when planting in August (Fig. 1A) due to after transplanting, it has continuously heavy raining in seedling stage between August and December and daily maximum temperature between 29.10 and $36.40^{\circ} \mathrm{C}$ (Fig. 3) that affected on seedling survival rate of 'Special' while 'Top Green', 'Green Queen' and 'Yok Kheo' had been less affected in the seedling stage (Nooprom et al., 2013a). 'Green Queen' had the earlier time to $50 \%$ flowering than other varieties in all planting dates (Fig. 1C). Different flowering times depended on the characteristics of broccoli variety (Nooprom and Santipracha, 2011). This result was consistent with time to $50 \%$ harvest; 'Green Queen' had the earlier time to $50 \%$ harvest than other varieties in all planting dates too (Fig. 1D). The early yield harvesting has a great impact on the marketing because of the higher prices (Nooprom et al., 2013a).

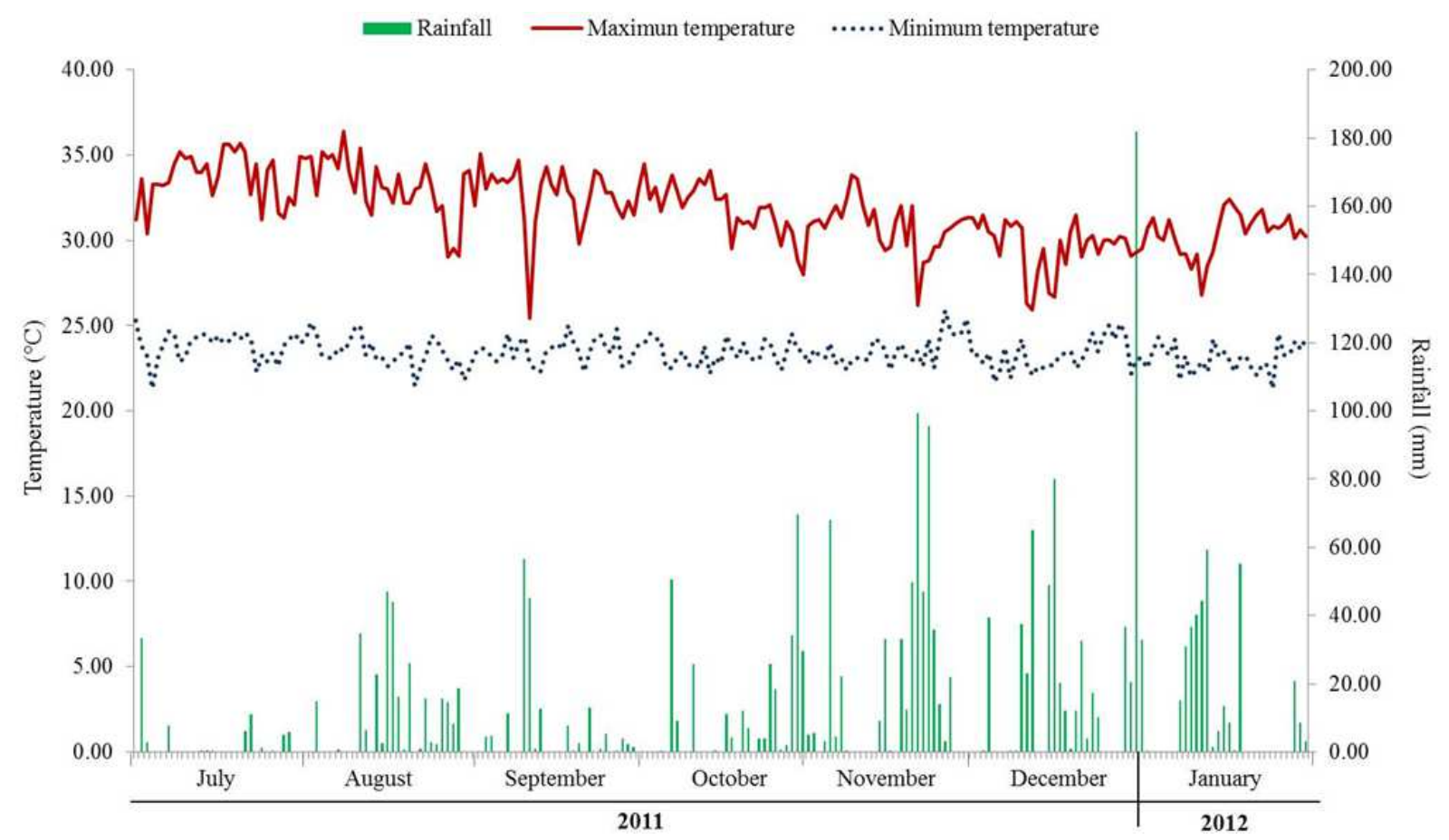

Fig. 3. Daily rainfall, maximum and minimum temperatures from July, 2011 to January, 2012 (Source: Kho Hong Agrometeorological Station, Hat Yai, Songkhla province, Thailand) 
In August and November, Top Green', 'Yok Kheo' and 'Special' had the latest times to $50 \%$ flowering and harvest because these periods had heavy raining and less sunlight which could cause time to $50 \%$ flowering and harvest delayed (Masari, 2001; Puwiwat, 2000). 'Yok Kheo' had the highest total yield (Fig. 2D) when planting in July and December because, after transplanting, there was not continually raining (Fig. 3) that broccoli could better growth than other planting dates. In September and October, the data of broccoli's growth and yield could not be recorded due to continuously heavy raining, resulted seedling all died except 'Green Queen' planted in September. One of the implications and limitations during rainy season was less sunlight quantity during those times created suitable environment for spreading of bacterium Erwinia corotovora ssp. corotovora and Xanthomonas campestris pv. campestris which causes soft rot and black rot diseases, respectively. According to Vodhivanich (2006) reported that black rot and soft rot diseases caused less growth and yield of Brassicaceae family. More extra researches may be needed in the future to evaluate the incidence of bacterial disease, growth and yield quality of broccoli as influenced by different rain protectors during rainy season in southern Thailand.

\section{CONCLUSION}

This study investigated the effects of planting dates and varieties on growth and yield during rainy season in southern Thailand. 'Yok Kheo' planting in July and December provides the best seedling survival rates, plant diameters, time to $50 \%$ flowerings, time to $50 \%$ harvests of $90.63-99.92 \%, 67.48-70.64 \mathrm{~cm}, 35.75-38.75$ DAT and 45.75-49.90 DAT, respectively. Yield responses, it provides the best harvested plants, head diameters, head weights and total yields of 76.34-80.04\%, 10.80$12.26 \mathrm{~cm}, 285.93-304.77 \mathrm{~g} /$ plant and 7.73-7.87 th $\mathrm{ha}^{-1}$, respectively. According to this study, we can recommend that the broccoli production during rainy season in southern Thailand should be selected by planting on July and December by using 'Yok Kheo' in these times because farmers would obtain higher yields than planting in other varieties.

\section{ACKNOWLEDGMENT}

This study was funded by a grant from The Office of the Higher Education Commission Thailand. Mr. Karistsapol Nooprom was supported by CHE Ph.D. Scholarship. The authors would like to thank The Graduate School and Department of Plant Science,
Faculty of Natural Resources, Prince of Songkla University, Hat Yai, Songkhla, Thailand, for supporting the scholarship, experimental equipment and the field that the broccoli was planted in.

\section{REFERENCES}

Decoteau, D.R., 2000. Vegetable Crops. 3rd Edn., Prentice Hall, Upper Saddle River, New Jersey, ISBN-10: 0139569960, pp: 464.

Dhillon, B.S., R.K. Tyagi, S. Saxena and G.J. Randhaw, 2005. Plant Genetic Resources: Horticultural Crops. 1st Edn., Narosa, New Delhi. ISBN-10: 8173195811, pp: 332.

Masari, A., 2001. Influence of light intensity on growth and yield of cauliflower under nethouse condition. MSc Thesis, King Mongkut's Institute of Technology Ladkrabang. Bangkok, Thailand.

Nooprom, A. and Q. Santipracha, 2011. Growth and yield of 7 early varieties of broccoli in Songkhla province. King Mongkut's Agric. J., 19: 54-61.

Nooprom, K., Q. Santipracha and S. Te-chato, 2013a. Effect of planting date and variety on growth and yield of broccoli during the dry season in Southern Thailand. Int. J. Plant Anim. Environ. Sci., 3: 121-124.

Nooprom, K., Q. Santipracha and S. Te-chato, 2013 b. Effect of shading and variety on the growth and yield of broccoli during the dry season in Southern Thailand. Int. J. Plant Anim. Environ. Sci., 3: 111-115.

Ouda, B.A. and A.Y. Mahadeen, 2008. Effect of fertilizers on growth, yield, yield components, quality and certain nutrient contents in broccoli (Brassica oleracea). Int. J. Agric. Biol., 10: 627-632.

Pornsuriya, P., P. Pornsuriya and S. Teeraskulchon, 1997. Study on broccoli production in Chonburi province. Kasetsart J. Nat. Sci., 32: 81-85.

Puwiwat, W., 2000. Growth and yield of nethouse cauliflower production under three shade levels. J. Agric., 13: 291-300.

Santipracha, Q., 2007. Vegetable Crop Variety and Growing Season of Southern Thailand. 1st Edn., Text J. Publication, Bangkok, pp: 22.

Vodhivanich, S., 2006. Vegetable Diseases and Their Control. 1st Edn., Kasetsart University Press, Bangkok, pp: 48. 